\title{
Mångfaldsarbetets förändringspotential \\ Insikter från sex engagerade företag
}

Charlotte Holgersson \& Laurence Romani

\section{Inledning}

Allt fler företag i Sverige försöker öka mångfalden bland sina anställda utifrån en övertygelse om att grupper bestående av olika personer är mer kreativa och innovativa och utifrån värderingar som är baserade på allas lika värde. Till exempel skriver en detaljhandelskoncern på sin hemsida: "Mångfald är nödvändigt för att vi ska kunna skapa inkluderande och innovativa företag. Mångfald och integration är en av de viktigaste samhälls- och hållbarhetsfrågorna just nu.” Detta kapitel handlar om det mångfaldsarbete som bedrivs i svenska företag och förändringspotentialen i detta arbete.

Även om svenskt arbetsliv i olika mätningar framstår som mer jämlikt och jämställt än i många andra länder pekar forskning på att det förekommer strukturell diskriminering utifrån en rad olika dimensioner (t.ex. SOU 2004:43, SOU 2006:60, SOU 2017:92). Det är tydligt att organisationer i samhällets alla sektorer präglas av olika typer av det Joan Acker (2006) kallar "ojämlikhetsregimer", det vill säga strukturer och kulturer som återskapar ojämlika villkor utifrån maktdimensioner såsom kön, klass och etnicitet (för en mer utförlig genomgång av begreppet, se Boréus, Neergaard \& Sohl, kapitel 1 ). Som Acker påpekar är ojämlikhet inbyggd i organisationer via den hierarkiska ordningen, där chefer har högre lön och mer makt och inflytande än exempelvis assistenter till chefer eller arbetare inom produktionen. Dessutom är 
själva idén om arbete utformad utifrån ett ideal där arbetaren är flexibel och tillgänglig utan några andra åtaganden i livet, ett ideal som främst gynnat män (Acker 1990). Ojämlikhetsregimer utvecklas även i organisationer som har som explicit mål att motverka ojämlikhet. Därmed kan organisationer ses som en arena där ojämlika maktrelationer i samhället upprätthålls.

Sociala rörelser har fört upp frågor om ojämlikhet på den politiska agendan, och i Sverige liksom i andra demokratiska länder finns det en politisk vilja att motverka ojämlikhet och sträva efter att individers mänskliga rättigheter respekteras. Denna vilja finns också i arbetslivet, på organisationsnivå, och kommer bland annat till uttryck i det förändringsarbete som äger rum under rubriken "mångfaldsarbete". Detta förändringsarbete sker emellertid under de villkor som råder, vilka i sig är ojämlika.

För att förstå vilken potential mångfaldsarbetet har att förändra är det viktigt att beskriva de praktiker som ingår i förändringsarbetet och synliggöra på vilka sätt förändringsarbetet dels återskapar, dels utmanar ojämlikhetsregimer. I det följande kommer vi att diskutera mångfaldsarbetets potential att förändra ojämlikhetsregimer i organisationer utifrån forskning om mångfaldsarbete och en studie av sex företag i Sverige som bedriver ett engagerat mångfaldsarbete.

\section{Från jämställdhetsarbete till mångfaldsarbete}

Med "jämlikhet" menas "rättvisa förhållanden mellan alla individer och grupper i samhället och utgår ifrån att alla människor har lika värde oavsett kön, etnicitet, religion, social tillhörighet med mera" (SCB 2018, 2), medan "jämställdhet" syftar specifikt på rättvisa förhållanden mellan könen. Jämlikhet och jämställdhet är politiska mål och som ett led i att nå dessa mål har lagar mot diskriminering stiftats. I Sverige stiftades den första lagen om jämställdhet i arbetslivet 1978, och 1994 kom lagen mot etnisk diskriminering. Sedan 2009 har Sverige en sammanhållen diskrimineringslag (SFS 2008:567) vars ändamål är att motverka diskriminering och på andra sätt främja lika rättigheter och möjligheter i arbetslivet, i skolan samt på universitet och högskolor (om 
diskrimineringslagen, se även Eriksson-Zetterquist, kapitel 10). Lagen omfattar sju diskrimineringsgrunder: kön, könsöverskridande identitet eller uttryck, etnisk tillhörighet, religion eller annan trosuppfattning, funktionsvariation, sexuell läggning samt ålder. Lagen innebär inte bara förbud mot direkt och indirekt diskriminering, trakasserier och sexuella trakasserier utifrån de sju diskrimineringsgrunderna utan har också proaktiva inslag: arbetsgivare med minst 25 anställda ska genomföra aktiva åtgärder för att uppnå lika rättigheter och möjligheter samt motverka diskriminering $\mathrm{i}$ arbetslivet utifrån diskrimineringsgrunderna.

På andra sidan Atlanten, i USA, antogs en lag om lika möjligheter (equal opportunities) 1964 som en del av Civil Rights Act för att säkerställa lika möjligheter till anställning oavsett ras, hudfärg, kön, religion och nationalitet. Denna lag kompletterades med krav om att organisationer som deltar i federala upphandlingar ska upprätta planer som beskriver hur de ämnar öka minoriteters och kvinnors deltagande på arbetsplatsen, så kallade affirmative action plans (Holvino \& Kamp 2009).

Lagstiftningen har påverkat det förändringsarbete som bedrivs av arbetsgivare och arbetstagare. I USA lanserade näringslivet diversity management som en reaktion mot lagstiftningen, som uppfattades vara alltför inriktad på att kompensera minoritetsgrupper och kvinnor för historiska oförrätter. Diversity management ska fokusera på att ta vara på skillnader mellan individer och grupper istället för behandla alla som om de vore lika. Ett argument är att det leder till bättre resultat för näringslivet. Detta affärsnyttoargument (business case) för mångfald har kommit att bli vanligt (Litvin 2000).

I Sverige började begreppet "mångfald" dyka upp under 1990-talet i samband med att frågor om invandring och integration hamnade på den politiska agendan. En diskurs som mer liknade den amerikanska diversity-diskursen blev mer framträdande mot slutet av 1990-talet. I en tidig rapport från Näringsdepartementet om mångfald i arbetslivet från år 2000 konstaterades det att Sverige var "ett land med en heterogen befolkning sammansatt av kvinnor och män, från olika samhällsklasser, med olika etniska bakgrunder, i alla åldrar, med olika sexuell läggning, utan eller med funktionshinder”. Rapportförfattarna skrev att alla mänskliga resurser måste tas tillvara på arbetsmarknaden för att trygga den ekonomiska tillväxten och välfärden i samhället, och att 
"samma möjligheter" också var en viktig rättvisefråga eftersom villkoren i arbetslivet har stor inverkan på människors livsvillkor i övrigt (Näringsdepartementet 2000). Under början av 2000-talet handlade mångfaldsarbetet i många svenska organisationer främst om integrering av första och andra generationens svenskar (Omanović 2009), men i och med den nya diskrimineringslagen har det blivit vanligare med en definition av mångfald som omfattar alla diskrimineringsgrunder som omfattas av lagen. På så sätt har mångfaldsarbete kommit att kopplas ihop med det antidiskrimineringsarbete som den svenska diskrimineringslagen påbjuder (Wahl m.fl. 2018).

Mångfaldsarbete i Sverige är inte lika institutionaliserat som diversity management i den nordamerikanska kontexten, men det har blivit allt vanligare (Leiva 2019). Till exempel framgick det i en undersökning 2015 bland 400 chefer i privat och offentlig sektor att 80 procent arbetade aktivt med mångfald, vilket var en ökning från 69 procent år 2013 (Proffice 2015). Idag går det till och med att tala om en internationell marknad inom mångfald, med konsulter, metoder, utbildningar, konferenser och handböcker (Holvino \& Kamp 2009; Oswick \& Noon 2014; Wahl m.fl. 2018).

\section{Forskning om mångfaldsarbete}

Forskningen om mångfald och mångfaldsarbete kan delas upp i två breda ansatser. Den första studerar hur en viss sammansättning av människor påverkar exempelvis innovation, kreativitet och problemlösning, i syfte att tillhandahålla bevis för att mångfald ger affärsnytta. Dessa studier har påvisat positiva resultat på flera nivåer. Özbilgin och kollegor konstaterade i en översikt (2014) av så kallade affärsnyttostudier att de positiva resultaten av mångfald kan avläsas på individnivå, exempelvis i form av ökat engagemang och större tillfredsställelse på jobbet, på gruppnivå i form av ökad kreativitet och mer effektivt beslutsfattande, och på organisationsnivå i form av bättre resultat, bättre rykte och ökat engagemang från det omgivande samhället. Samtidigt påpekade de att det finns studier som visar att mångfald också kan ha negativa konsekvenser på dessa nivåer: kommunikationsproblem, brist 
på sammanhållning och konflikter. Dessa negativa resultat förklaras ofta med att det inte räcker med mångfald vad gäller sammansättningen av människor för att det ska ge positiva effekter på affärsnyttan. Det behövs också en kultur som är inkluderande. Med "inkludering" menas vanligtvis att individer upplever att de får vara del av viktiga processer i organisationen eller att de kan bidra fullt ut och på ett effektivt sätt till organisationen (Roberson 2006).

Den andra ansatsen pekar på utmaningar i själva arbetet för att åstadkomma mångfald och inkludering. Exempelvis har forskning om mångfaldsarbete i en nordamerikansk kontext visat att mycket av detta arbete inte har varit så framgångsrikt (Kalev m.fl. 2006; Kulik \& Roberson 2008), och ibland till och med har motverkat jämlikhet genom att stereotypa föreställningar om minoritetsgrupper har förstärkts och majoritetsgruppens negativa inställning till minoritetsgrupper har underblåsts (Bond \& Pyle 1998; Linnehan \& Konrad 1999). Denna ansats brukar gå under benämningen "kritisk mångfaldsforskning" (critical diversity studies).

Enligt kritisk mångfaldsforskning handlar en av utmaningarna i mångfaldsarbetet om hur vi pratar om mångfald och hur vi formulerar problemet. Det saknas ett maktperspektiv i de två dominerande sätten att se på olikheter (Holvino \& Kamp 2009), att olikheter antingen är individuella eller kopplade till sociodemografiska kategorier. Utan ett maktperspektiv framstår skillnader mellan olika sociodemografiska kategorier som resultat av essentiella skillnader i attityder, personlighet och beteende som individer som tillhör dessa grupper delar. Därmed reduceras individer till att vara medlemmar i en viss sociodemografisk kategori, såsom "kvinna", "lågutbildad" eller "migrant", utan någon större hänsyn till individuella skillnader eller variationer inom kategorierna. Förändringsstrategier som utgår från stereotypa föreställningar om olika kategorier cementerar snarare än förändrar maktojämlikheter. Om fokus istället ligger på individuella skillnader, utan hänsyn till maktstrukturer, leder det till förändringsstrategier som syftar till att göra systemet tillgängligt för alla men inte nödvändigtvis till att problematisera eller förändra systemet i sig (Janssens \& Zanoni 2014).

Kritisk mångfaldsforskning vänder sig också mot att mångfaldsarbetet ofta motiveras av att olikheter ska generera affärsnytta. Om olikheterna 
dessutom ses som essentiella finns det inga incitament att förändra villkoren, och exempelvis kvinnor och minoritetsgrupper riskerar att fastna i branscher, positioner och uppgifter där anställningsvillkoren och möjligheterna till utveckling kan vara sämre (Holvino \& Kamp 2009). Jakten på affärsnytta inbjuder också till en tro på att mångfald kan uppnås på samma sätt som andra affärsmål, med hjälp av en mer eller mindre standardiserad uppsättning metoder (se t.ex. Ashcraft 2009; Kelly \& Dobbin 1998; Lorbiecki \& Jack 2000; Zanoni \& Janssens 2004).

\section{Kunskap utvecklad i samarbete}

Detta kapitel handlar om mångfaldsarbetets potential att förändra ojämlikhetsregimer i organisationer. Vi utgår från empiriskt material från sex svenska företag som anser att mångfald är en strategiskt viktig fråga för verksamheten: ett medelstort logistikföretag, ett stort it-företag, ett medelstort it-företag, ett stort finansföretag, ett medelstort kemiföretag, en stor detaljhandelskoncern och en stor handelskoncern. Vi vill dels ge en bild av hur mångfaldsarbete kan se ut i svenskt näringsliv idag, dels förmedla insikter om vad som kan främja arbetet för förändring och vad som kan försvåra det.

I de följande avsnitten kommer vi först att introducera utgångspunkterna för vår studie och därefter de studerade företagen och deras mångfaldsarbete. Vi presenterar företagens olika sätt att definiera mångfald, deras mångfaldsstrategier och motiv samt de vanligaste metoderna som används. Med utgångspunkt från kritisk mångfaldsforskning kommenterar vi löpande på vilka sätt detta förändringsarbete kan bidra till att återskapa och motverka ojämlikheter. Vi är dock inte ute efter att utvärdera de studerade företagens mångfaldsarbete, utan tar deras arbete som en utgångspunkt för en mer allmän diskussion om vad som kan främja respektive motverka förändring. I en slutdiskussion lyfter vi fram tre aspekter som påverkar mångfaldsarbetets förändringspotential: vilja till förändring, kunskap om ojämlikhet och förändringsarbete. 


\section{Våra utgångspunkter}

Vår diskussion bygger på empiriskt material som samlats in inom ramen för ett forskningsprojekt som finansierades av Ragnar Söderbergs Stiftelse och som involverade fem forskare och ett tiotal organisationer, främst företag, i Sverige och Danmark. Materialet samlades in genom dokumentanalyser, intervjuer och deltagande observationer. Organisationerna är myndigheter i Sverige och Danmark samt företag i branscher såsom it, logistik, kemi, utbildning och bank och finans. Det organisationerna har gemensamt är en stark ambition att aktivt arbeta för mångfald och inkludering. Det innebär inte att de nödvändigtvis präglas av jämlikhet, har lång erfarenhet av mångfaldsarbete eller har en välutvecklad mångfaldsstrategi. Däremot går deras ambition bortom att bara ha några väl valda ord om mångfald på hemsidan. Eftersom vår diskussion i detta kapitel fokuserar på svenskt näringsliv har vi valt att utgå från de företag i studien som är baserade i Sverige.

Vårt förhållningssätt som forskare hämtar inspiration från Meyersons och Scullys (1995) begrepp tempered radicals, på svenska "lagomrebeller" (Callerstig 2011). Lagomrebeller vill förändra systemet på dess egna villkor och arbetar inom en organisationsstruktur som de samtidigt ifrågasätter och försöker förändra på en grundläggande nivå. För oss som forskare har det inneburit att vi ingick i samarbeten med organisationer och att vi eftersträvade en dialog och gemensamt lärande. Vi har agerat som empatiska samtalspartner när vi tillsammans har undersökt de svårigheter som våra kontaktpersoner upplever. I dessa samtal har vi ställt förtydligande frågor och på ett vänligt sätt även kunnat ställa utmanande frågor som därigenom potentiellt öppnat för nya riktningar i förändringsarbetet (jfr King \& Learmonth 2015; Wickert \& Schaefer 2015).

I analysen av vårt material har vi utgått från kritiska mångfaldsstudier. Vi vill ta vara på insikter från den kritiska mångfaldsforskningen för att hitta nya infallsvinklar på mångfaldsarbete och därigenom bidra till kunskap om hur organisationer kan verka för ökad jämlikhet inom en kontext som i sig är ojämlik (jfr Janssens \& Zanoni 2014). 


\section{Definitioner av mångfald}

Företagen i vårt material definierar mångfald på olika sätt men genomgående är definitionerna breda. Detaljhandelskoncernen definierar mångfald utifrån identitetsgrupper som återfinns bland deras anställda samt mindre tydliga dimensioner såsom lärstil och förmågor. Finansföretaget definierar mångfald utifrån lagstiftningens diskrimineringsgrunder, medan kemiföretaget väljer att inte definiera vad som menas med mångfald eftersom de inte vill riskera att stereotypisera någon.

En bred definition som omfattar alla typer av individuella skillnader kan framstå som tilltalande. Breda definitioner kan få alla i organisationen att känna sig inkluderade eftersom varje medarbetare identifieras som annorlunda och organisationen framstår som en plats där skillnader och kompetenser värderas. Det kan minska motståndet mot mångfaldsarbete hos dominerande grupper i en organisation (Janssens \&Zanoni 2014). Men det kan också lätt leda till att kulturella skillnader, kognitiva skillnader och skillnader i makt behandlas som om de vore samma sak, vilket osynliggör ojämlika maktstrukturer. Det kan också ge intrycket att diskriminering handlar om individuella fördomar snarare än om strukturell förfördelning (Holvino \& Kamp 2009). Därmed minskar mångfaldsarbetets förändringspotential, eftersom det inte blir tydligt för medarbetare och chefer på vilket sätt organisationens rådande strukturer och kulturer är problematiska.

Det är också vanligt att de breda definitionerna förmedlar en syn på mångfald som ett gruppfenomen utifrån vissa utvalda dimensioner kring vilka ojämlikheter historiskt har formats, såsom kön, etnicitet och sexuell läggning. Flera av de företag vi studerade kopplar sin definition av mångfald till de diskrimineringsgrunder som identifieras i lagstiftningen, vilket tycks hjälpa dem att se bristen på mångfald inte bara som ett resultat av individuella skillnader utan som något mer strukturellt. Den nära kopplingen till diskrimineringsgrunderna kan dock vara begränsande med tanke på att det finns dimensioner som inte omfattas av lagstiftningen, exempelvis klass. Samtidigt visar forskning att en bred definition av mångfald kan göra det möjligt för organisationer att lägga till ytterligare dimensioner, såsom just klass (Leiva 2019). Vidare finns det en risk för att en syn på mångfald som ett gruppfenomen gör 
att anställda som tillhör historiskt underordnade grupper reduceras till sin grupptillhörighet och fråntas sin subjektivitet och sitt agentskap (Zanoni \& Janssens 2004).

Holvino och Kamp (2009) lyfter fram att ett fokus på individuella skillnader leder till strategier för att säkerställa att alla har samma tillträde till positioner, exempelvis individuell kompetensutveckling genom utbildning och mentorskap, medan ett fokus på gruppbaserade skillnader leder till ett diskriminerings- och rättviseperspektiv där målet är att bli av med strukturella ojämlikheter som drabbar historiskt förfördelade grupper, exempelvis genom att göra särskilda rekryteringssatsningar och skapa allianser mellan olika historiskt förfördelade grupper för att öka deras representation och ge dem mer makt.

Av de sex företag som vi studerar i detta kapitel är det visserligen flera som erbjuder utbildningar samt trainee- och mentorprogram för underrepresenterade grupper såsom kvinnor och personer med utländsk bakgrund, men flera satsar också på att utbilda chefer och anställda om omedvetna fördomar och diskriminering exempelvis i samband med rekryteringar. Det tycks alltså som om de ser skillnader som såväl individuella som gruppbaserade.

En väg ur dilemmat med individuella kontra gruppbaserade skillnader skulle kunna vara att betrakta skillnader som sociala konstruktioner, det vill säga som något som vi skapar gemensamt, som har en flytande innebörd och som varierar beroende på kontext. Detta förhållningssätt inbjuder till frågor om varför skillnader förstås på ett visst sätt i en viss kontext och vad det får för konsekvenser för skapandet och upprätthållandet av ojämlikheter (Holvino \& Kamp 2009; Schwabenland \& Tomlinson 2015). Men eftersom dessa frågor kan vara svåra att besvara och det finns en förkärlek för snabba lösningar i arbetslivet framstår inte förhållningssättet alltid som så attraktivt för chefer (Noon 2007).

\section{Företagens mångfald och strategier}

Ett vanligt sätt att identifiera var det föreligger problem med mångfald och att följa upp sitt förändringsarbete är att kartlägga exempelvis olika könsfördelningar. Det kan dock vara en utmaning att kartlägga en organisations mångfald eftersom det dels är svårt att definiera mångfald, dels 
finns lagstiftning som begränsar möjligheten att kartlägga anställdas sexuella läggning, etnicitet och andra diskrimineringsgrunder. Kartläggningar utifrån kön är emellertid vanligt förekommande. I vårt material kan vi konstatera att kemiföretaget, finansföretaget, detaljhandelsföretaget och handelskoncernen har en jämn könsfördelning bland sina anställda, medan de båda it-företagen är mansdominerade. Dessa fördelningar överensstämmer med hur det allmänt ser ut i deras respektive branscher. Samtidigt präglas alla företag av en vertikal könssegregering, det vill säga att kvinnor och män återfinns på olika funktioner och i olika roller. På högre chefspositioner har dock alla företag utom kemiföretaget och it-företagen en så kallad balanserad könsfördelning som ligger inom spannet 40-60 procent för vardera kön.

Vi har inte lika mycket information vad gäller andra diskrimineringsgrunder. Personuppgiftslagen (PUL) tillåter inte att uppgifter som indikerar "ras", etnisk bakgrund eller religiös övertygelse samlas in utan medarbetares samtycke. Dessutom finns ingen entydig definition av "etnicitet" (jfr resonemangen om möjligheterna att lönekartlägga för att motverka ojämlikhet i Boréus m.fl., kapitel 9). I Sverige ses etnicitet vanligtvis som ett samlingsbegrepp för synliga drag såsom hudfärg eller synliga religiösa symboler, samtidigt som det också kan syfta på aspekter såsom födelseort, nationalitet samt kultur- och språkfärdigheter. En del svenska organisationer kartlägger sin etniska sammansättning genom att anlita Statistiska Centralbyrån (SCB), som kan tillhandahålla information om andelen anställda som är inrikes eller utrikes födda. Andra sätt att kartlägga etnicitet är att kategorisera och räkna förekomsten av olika typer av namn, eller så får chefer uppskatta variationen $\mathrm{i}$ etnisk tillhörighet bland medarbetarna (Wahl m.fl. 2018). Några av de företag vi har studerat har kartlagt andelen utrikes- och inrikesfödda, andra har tittat på de anställdas namn för att uppskatta den etniska sammansättningen. Vi ser dock att samtliga företag har etniskt homogena ledningsgrupper och högre chefsled men att det endast är det stora it-bolaget, kemiföretaget och detaljhandelskoncernen som har etnisk mångfald bland sina anställda.

Samtliga sex företag har någon form av dokument som förtydligar företagets förhållningssätt till mångfald. Som Wahl m.fl. (2018) konstaterar liknar mångfaldsarbete andra former av organisatoriskt för- 
ändringsarbete, och i detta arbete ingår det att formulera långsiktiga och kortsiktiga mål samt att identifiera, implementera, följa upp och utvärdera åtgärder som ska hjälpa organisationen att nå målen. Ibland sammanfattar organisationer sina övergripande målsättningar, ansatser och tillvägagångssätt i ett policydokument som får utgöra ett ramverk för arbetet. Policyn kan vara separat eller integreras i andra regelverk såsom personalpolicyn eller arbetsmiljöpolicyn, och även i företagets mål-, visions- och värdegrundsdokument. I de studerade företagens policydokument om mångfald finns det tydliga referenser till diskrimineringslagen och formuleringar om att företaget motsätter sig alla former av diskriminering och trakasserier utifrån de sju diskrimineringsgrunderna.

På logistikföretaget har mångfald inte funnits på den strategiska agendan så länge, medan de andra företagen har arbetat längre med mångfald. Särskilt jämställdhet har varit i fokus i många år på båda it-företagen, på finansföretaget, i detaljhandelskoncernen och i handelskoncernen. På några av företagen är mångfald en tydlig del av strategin och har kopplats till företagets värdegrundsarbete, det vill säga företagets aktiva arbete med att utveckla företagskulturen och fastställa vilka värderingar de vill ska prägla denna kultur. Det verkar underlätta för chefer och medarbetare att förstå varför mångfald är viktigt för verksamheten och hjälpa dem motivera olika initiativ och handlingar om mångfald har kopplats till ett aktivt värdegrundsarbete. Till exempel berättade en chef i logistikföretaget att hen hade anställt en person som inte talade så bra svenska, men väl engelska, till sin enhet och motiverade detta med att företaget värderade mångfald och att ett av de tre ledorden för företagets värderingar var "mod". Chefen tyckte det var modigt att våga anställa någon som uppfattades som annorlunda. Det visade sig att det inte hade varit något problem på arbetsplatsen att medarbetaren inte talade perfekt svenska, och många kunder talade lika gärna, eller till och med hellre, engelska. På det medelstora it-företaget var jämlikhet och mångfald tydliga delar av strategin, de bedrev ett omfattande värdegrundsarbete och hade en jämlikhetsklausul inskriven i sina kontrakt med kunder, och det hade underlättat för chefer att ingripa när deras medarbetare hade blivit utsatta för diskriminering $\mathrm{i}$ kontakt med kunder. 
Det visar sig också vara betydelsefullt att ägarna, styrelsen och högsta ledningen är tydligt engagerade och drivande i värderings- och mångfaldsarbetet. På logistikföretaget talar chefer och personer inom HR (human resources) om hur betydelsefullt det är med både det stöd som ägarna ger och de krav som de ställer på företaget vad gäller mångfaldsarbetet. Detta känns igen från forskning om förändringsarbete generellt och mångfaldsarbete mer specifikt: ledningen har den formella makten att genomdriva förändring och en symbolisk makt som skänker förändringsarbetet trovärdighet och legitimitet (Wahl m.fl. 2018). Deras stöd är inte minst viktigt i värdegrunds- och mångfaldsarbetet. Flera av de studerade företagen har tydliggjort att det är cheferna som ska driva mångfaldsarbetet och att deras insatser utvärderas, vilket är en tydlig signal om att mångfald är strategiskt viktigt. På de företag där betydelsen av mångfald inte kommuniceras lika tydligt är inte heller cheferna lika benägna att prioritera frågorna.

\section{Olika motiv till mångfaldsarbete}

Motiveringarna till varför mångfald är en viktig strategisk fråga varierar bland de studerade företagen. De skriver i sina dokument att mångfald är viktigt för att vara en attraktiv arbetsgivare, att attrahera och ta tillvara en bredare kompetens, vara mer innovativa, att förstå kunder bättre och att ta ett samhällsansvar. Flera skriver att mångfald är rätt både för att det handlar om mänskliga rättigheter och för att det är bra för affärerna. Dessa argument känner vi igen från andra organisationer. Forskning visar att kompetensargumentet utgår från idén om att organisationen kan tillgodogöra sig nya kompetenser, perspektiv och erfarenheter om den rekryterar och utvecklar människor som skiljer sig från dem som redan finns i organisationen (Wahl m.fl. 2018). Detta argument är ofta kopplat till tanken om att organisationen ska avspegla sina kunder eller andra viktiga intressenter, både för att kunna leverera produkter och tjänster som är relevanta och av god kvalitet och för att framstå som trovärdiga och legitima inför exempelvis potentiella medarbetare, media och allmänheten. Kompetensargumentet länkas inte sällan samman med tankar om att heterogena grupper är mer innovativa och att ökad mångfald också ökar organisationens innovationsförmåga (ibid.). 
Flera av de företag vi studerat för också fram tanken att mångfald är viktigt för att alla ska trivas och få vara sig själva på jobbet. Det kan kopplas till de senaste årens ökade fokus på inkludering. Det har vuxit fram ett resonemang om att mångfald främst handlar om representation och fördelningar och att en heterogen grupp inte per automatik fungerar bra och är kreativ, utan det krävs dessutom en inkluderande kultur (Oswick \& Noon 2014). Det talas idag alltmer om mångfaldsarbete i termer av "mångfald och inkludering" (diversity and inclusion, ofta förkortat "D\&I").

Kompetensargumentet kopplas i flera av företagen vi studerat till ett affärsnyttoargument, det vill säga att mångfald är bra för affärerna. De flesta söker emellertid överbrygga spänningen mellan affärsnyttoargumentet och rättviseargumentet genom att exempelvis se mångfald som en del av hållbarhet eller centralt för företagets värderingar. Som en effekt av ökad kritisk granskning och krav på ökad transparens har det blivit allt vanligare att privata företag på olika sätt i sina policydokument tar upp FN:s mänskliga rättigheter och de globala hållbarhetsmålen (Wahl m.fl. 2018).

Inget av de studerade företagen uttrycker tydligt att mångfaldsarbetet handlar om att omfördela makt, till exempel att syftet med mångfaldsarbetet skulle vara att öka kvinnors och minoritetsgruppers inflytande över hur verksamheten utformas och vilka beslut som fattas. Sådana motiveringar är mer legitima och därför också vanligare inom kommunal och statlig verksamhet, som förväntas sträva mot det jämställdhetspolitiska målet att alla oavsett kön ska ha samma makt att utforma samhället och sina egna liv (Wahl m.fl. 2018).

\section{Metoder i mångfaldsarbete}

De organisationer vi har studerat använder flera metoder i sitt mångfaldsarbete. I det följande tar vi upp dem som är vanligast i vårt material: rekrytering och befordran, mentorprogram, nätverk och arbetsgrupper samt utbildning. 


\section{Rekrytering och befordran}

Flera av de studerade organisationerna har gjort en översyn av sina rekryterings- och befordringsförfaranden. Logistikföretaget har helt sett över sitt rekryteringsförfarande och granskat hur kompetens identifieras och värderas, på det stora it-företaget finns det numera krav på att det ska finnas minst en slutkandidat av vardera kön och på det medelstora it-företaget kallas alla kvinnliga kandidater till intervju på de positioner där det generellt sett är få kvinnliga sökande. Att formalisera rekryterings- och befordransprocesser och skapa tydligare kriterier för urval och befordran, utvärderingar och lönesättning är vanliga åtgärder inom mångfaldsarbete. Det ses som ett sätt att minska påverkan av den dominerande gruppens godtycke och fördomar på olika beslut och därmed minska risken för diskriminering. Forskning pekar emellertid på att en formalisering av HR-praktiker inte helt eliminerar beslutsfattarnas godtycke eller nödvändigtvis förändrar hur HR-systemen värderar kompetenser och förmågor. Därför finns det en överhängande risk att de kompetenser och förmågor som den dominerande gruppen anses besitta fortsätter att premieras av systemen (Janssens \& Zanoni 2014).

Några av de studerade företagen har riktade satsningar för att attrahera kandidater från underrepresenterade grupper. Via samarbeten med myndigheter och ideella organisationer deltar flera av de studerade företagen i initiativ för att öka rekryteringen av migranter och långtidsarbetslösa. En utmaning här är att även om företagets rekryteringar på lägre nivåer präglas av mångfald betyder det inte att utvecklingsmöjligheterna är likvärdiga för alla. Detta var tydligt i kemiföretaget: deras rekryteringsförfarande och samarbeten ledde till att företaget hade en mångfald bland personalen på lägre nivåer, men det saknades tydliga initiativ för att förändra dessa personers utvecklingsmöjligheter och på högre nivåer rådde klart bristande etnisk mångfald. Detta kan härledas till det som postkolonial teori kallat "andrafiering", det vill säga att poängtera hur annorlunda en medlem av en underordnad grupp är och därigenom legitimera hens underordnade position. I vårt material finns chefer som berättar hur trevligt det är med personer med utländsk bakgrund eftersom de är så tacksamma för att de har fătt ett jobb, inte är så intresserade av att göra karriär och är mer lojala med företaget 
än vad svenskar är. Genom att bortse från att "tacksamhet", "nöjdhet" och "lojalitet" kan vara resultatet av en utsatt position på arbetsmarknaden går arbetsgivarna miste om att upptäcka dessa anställdas fulla potential. De kommer därför fortsatt att behandla dem som annorlunda och erbjuda dem sämre utvecklingsmöjligheter (Romani m.fl. 2019).

I några företag hade mångfaldsarbetet $i$ sig blivit ett kriterium vid rekrytering och utvärdering för befordran. Exempelvis följde finansföretaget som en del av prestationsbedömningen upp hur väl chefer hade lyckats uppnå sina jämställdhets- och mångfaldsmål. Några av företagen försökte påverka utfallet av rekryterings- och befordringsprocesserna genom att sätta upp mål för rekryteringar, särskilt på chefsnivåer. Det är förhållandevis vanligt i större organisationer (Wahl m.fl. 2018). Kvotering, det vill säga att platser reserveras för personer ur en viss grupp utan hänsyn till kompetens, är inte tillåtet i Sverige eller EU. Däremot är det tillåtet med positiv särbehandling vad gäller kön, vilket innebär att en arbetsgivare i en rekrytering kan välja en person av underrepresenterat kön som har lika eller likartade meriter (ibid.). Beroende på hur rekryteringsmål implementeras och följs kan de bidra till förändringsarbetet. Våra intervjupersoner vid logistikföretaget vittnade om att de fördelningsmål vad gällde kön och internationell bakgrund på chefspositioner som ägarna hade satt upp var en pådrivande faktor för mångfaldsarbetet. På det stora it-företaget fanns ett mål för andelen kvinnor på chefsbefattningar, men ledningen prioriterade inte att sträva efter att det skulle uppnås och det gjorde därmed inte heller av chefer på lägre nivåer såvida de inte själva ansåg att målet var viktigt.

\section{Mentorprogram}

I Sverige har mentorprogram varit ett populärt inslag i företagens jämställdhetsarbete (SOU 2014:80), och idag finns det även mentorprogram för personer med utländsk bakgrund. Flera av företagen i vår studie skickade medarbetare som mentorer till den typen av mentorprogram. Tanken bakom formaliserade mentorsrelationer är att eftersom relationer med överordnade är avgörande för karriären ska personer ur underrepresenterade grupper få tillgång till ett utvidgat nätverk (Wahl m.fl. 2018). 
Mentorprogram kan vara organiserade på olika sätt, kan vara externa eller interna och kan innehålla olika mycket utbildning. Vilken sorts kunskap som förmedlas kan också variera (Wahl m.fl. 2018; Benschop m.fl. 2015). Metoden har fått kritik eftersom den lätt sänder budskapet att det är adepten som ska lära av mentorn hur hen ska gå tillväga för att göra karriär. Det kan visserligen vara till hjälp för adepten på individnivå, men det leder inte nödvändigtvis till något lärande för mentorn eller någon förändring på organisationsnivå. Det finns emellertid mentorprogram som har visat sig ha en större förändringspotential. Dessa fokuserar på ett ömsesidigt lärande mellan mentor och adept och bygger på kunskap om ojämlika maktrelationer (Benschop m.fl. 2015).

Den typ av mentorprogram som förekommer på de företag vi studerade är sådana där en anställd får möjlighet att agera mentor för en person som nyligen kommit till Sverige. Programmen verkar ha ambitionen att ge möjlighet till ömsesidigt lärande och utgår från kunskap om ojämlikheter i samhället. Att döma av våra intervjuer kan de ha positiva effekter på individnivå: adepterna får kontakt med personer som är etablerade på arbetsmarknaden som kan agera som referenser, och mentorer vittnar om att de har lärt sig mer om andra kulturer. Potentialen för organisatorisk förändring tycks emellertid vara begränsad just på grund av att metoden främst är inriktad på individnivån.

\section{Nätverk och arbetsgrupper}

I flera av företagen vi studerat finns nätverk, exempelvis för kvinnor och hbtq-personer, vilket är en annan etablerad metod för mångfaldsarbete. Nätverk samlar ofta en underrepresenterad grupp i organisationen och utgör en arena för information, råd och stöd. De kan göra det möjligt att driva frågor som kan vara svåra för enskilda individer att driva på grund av den utsatthet det medför att tillhöra en underrepresenterad grupp (Wahl m.fl. 2018). Nätverk och arbetsgrupper kan också samla anställda som är engagerade i mångfaldsfrågor och utgöra en resurs för ledningen genom att komma med information och förslag till förändring samt agera som intressenter och driva på frågorna gentemot ledningen (ibid.). På det mellanstora it-företaget fanns det både en grupp som driver jämställdhets- och mångfaldsfrågor på företaget i samråd 
med ledningen och ett löst sammanhållet nätverk som samlar anställda som vill lära sig mer om jämställdhet och mångfald.

Nätverk som metod har fått kritik för att det är ett enkelt sätt för ledningen att praktisera läpparnas bekännelse samtidigt som det kan leda till ökad isolering av icke-dominerande grupper. Nätverkens förändringspotential är avhängig av att de har ett explicit uppdrag att verka för förändring av organisationen eftersom det då finns en möjlighet att de kommer att påtala ojämlikheter i organisationen. Samtidigt finns det en risk för att ansvaret för förändringen förskjuts från ledningen till nätverkens och arbetsgruppernas medlemmar (Benschop m.fl. 2015).

\section{Utbildning}

I princip alla företag i studien tillhandahöll utbildningar som en del av sitt mångfaldsarbete. Det är en av de vanligaste metoderna i mångfaldssammanhang, men utformningen kan variera (Wahl m.fl. 2018).

Utbildningen kan vara inriktad på att höja yrkeskompetensen hos personer från underrepresenterade grupper, exempelvis kvinnor i mansdominerade yrken, i syfte att bryta segregeringen på arbetsmarknaden. Idag är det dock vanligt att denna typ av kompetenshöjande insatser riktas till migranter för att hjälpa dem att komma in på arbetsmarknaden (ibid.). Till exempel arrangerar detaljhandelskoncernen vi studerat ett ledarutvecklingsprogram som syftar till att identifiera och utveckla potentiella ledare med utländsk bakgrund. Eftersom denna typ av ledarutvecklingsprogram vanligtvis har ett individfokus blir förändringspotentialen på organisationsnivå begränsad.

Vanligast är emellertid utbildningar som syftar till att sprida medvetenhet och kunskap om mångfaldsfrågan (Benschop m.fl. 2015). Formatet kan vara allt från traditionella föreläsningar som ska skapa medvetenhet om problemen med brist på mångfald och mervärdet av mångfald till mer interaktiva utbildningar som går ut på att öka kunskap om mångfald och innehåller kommunikationsövningar, gruppdiskussioner och rollspel om skillnader (ibid.). På de studerade företagen förekommer både utbildningar som alla anställda måste genomgå och särskilda satsningar, ibland riktade till chefer, eller som inslag i befintliga utbildningar såsom ledarskapsutbildningar. Logistikföretaget genomförde en 
omfattande satsning med en skräddarsydd utbildning i workshopformat om mångfald och inkludering som alla anställda genomgick och som leddes av cheferna.

Mångfaldsutbildningar kan förmedla olika typer av budskap. Anand och Winters (2008) har identifierat tre ansatser: "diskriminering och rättvisa", som fokuserar på antalsmässiga fördelningar och lagstiftning och bidrar till assimilering och konformism; "tillgänglighet och legitimitet", som främjar acceptans och hyllar skillnader ur ett affärsnyttoperspektiv; och "lärande och integrering", som synliggör olika perspektiv och fokuserar på lärande och personlig utveckling. Anand och Winters pekar på att forskningen har kritiserat både "diskriminering och rättvisa"-perspektivet och "tillgänglighet och legitimitet"-perspektivet för att de underlåter att synliggöra och problematisera makt och förmedlar en harmonisk syn på skillnader. "Lärande och integration"-perspektivet, däremot, för fram att det är maktrelationer som måste förändras för att allas perspektiv ska bli lika legitima och för att organisationen ska förändras. Utbildningarna på flera av de studerade företagen innehåller inslag som rör makt, men det är "tillgänglighet och legitimitet"-perspektivet som dominerar (ibid.).

Ett populärt tema i näringslivet i stort och inom de studerade företagen är utbildningar i unconscious bias, det som på svenska brukar kallas "omedvetna fördomar". Dessa utbildningar syftar till att synliggöra bakomliggande orsaker till omedvetna fördomar och vilka konsekvenser fördomarna får. Enligt Wahl m.fl. (2018) kan utbildningarna utmana föreställningen att enskilda individer är objektiva och neutrala och därigenom synliggöra hur individuella attityder och beteenden kan kopplas till maktstrukturer i organisationer och samhället. Samtidigt räcker det inte att ha insikter om sina fördomar för att ens beteende ska förändras, och insikterna leder inte heller automatiskt till att organisatoriska praktiker förändras (Kalev m.fl. 2006; Noon 2018). Flera av intervjupersonerna som hade ansvar för att driva mångfaldsarbetet $\mathrm{i}$ de studerade företagen var tydliga med att utbildningar om omedvetna fördomar inte var tillräckliga för att förändra beteenden. Däremot såg de utbildningarna som en av flera byggstenar; andra byggstenar kunde vara att se över rekryteringsrutiner och upprätta checklistor som hjälper chefer att inte falla tillbaka i gamla beteendemönster. 


\section{Mångfaldsarbetets förändringspotential: vilja, kunskap om ojämlikhet och förändringsarbete}

Vi vill i detta avslutande avsnitt lyfta fram tre aspekter av mångfaldsarbetet som påverkar arbetets potential att få till stånd verkliga förändringar: viljan att skapa mångfald och motarbeta ojämlikheter, kunskap om ojämlikhet och kunskap om förändringsarbete.

En uttalad vilja att skapa mångfald och motarbeta ojämlikheter bidrog i våra studerade företag till att chefer och medarbetare agerade annorlunda i olika sammanhang. Det medelstora it-företaget kommunicerade mycket tydligt sin vilja att komma tillrätta med sin skeva könsfördelning, både i skrift och bild samt i chefers uttalanden. Det gjorde visserligen att kvinnor i organisationen kunde känna press på grund av den ökade uppmärksamheten, men det var en stark signal om att kvinnors kompetens var efterfrågad och att de var uppskattade som medarbetare. Argument för mångfald som handlar om att ta tillvara kompetens riskerar att föra med sig en essentialistisk och utilitaristisk syn på identiteter. Sådana argument är dock viktiga eftersom anställda som anses besitta värdefull kompetens har en mer fördelaktig maktposition. Janssens och Zanoni (2014) visar att när etniska minoriteter kopplas ihop med värdefull kompetens motverkar det föreställningar om att medlemmar av etniska minoriteter generellt har lägre kompetens. På det medelstora it-bolaget vi studerade innebar den uttalade viljan att manliga chefer ansträngde sig mer för att stödja kvinnor i karriären. Den innebar också att kvinnor kände sig bemäktigade att påtala ojämställda förhållanden och att både kvinnor och män engagerade sig i företagets förändringsarbete. Den uttalade viljan kan därmed sägas ha öppnat för ett synliggörande och ifrågasättande av normer och bidragit till att skapa ett utrymme för ömsesidigt lärande mellan majoritetsoch minoritetsgrupper i organisationen (jfr Janssens \& Zanoni 2014; Holgersson \& Romani 2020).

Mångfaldsarbetets förändringspotential påverkas också av nyckelpersoners kunskap om ojämlikheter och deras konsekvenser. Även om våra intervjupersoner tyckte att mångfald var viktigt på ett principiellt plan var det inte alltid de kunde förklara på vilket sätt ojämlikhet var ett problem för själva verksamheten. Vidare kunde kunskapen om 
ojämlikhet vara ojämnt fördelad bland medarbetare och cheferna. På det medelstora it-företaget var kunskapsnivån hög bland cheferna, vilket gjorde att de till exempel var mer uppmärksamma på hur de bedömde kvinnor och män i rekryterings- och befordranssammanhang. På det stora it-företaget fanns det personer på höga nivåer inom HR som hade goda kunskaper om ojämlikheter, medan personer inom HR på lägre nivåer inte var lika kunniga. Att dessa personer inte riktigt förstod problematiken medförde att de inte kunde stödja chefer i att exempelvis rekrytera för ökad mångfald eller införa inkluderande arbetssätt, och deras frustration och dåliga samvete kring mångfaldsfrågorna försvårade arbetet (jfr Schwabenland \& Tomlinson 2015).

Den tredje aspekten, kunskap om förändringsarbete, inbegriper kunskap om förändringsstrategier och metoder. Att förstå problemen med ojämlikhet innebär inte per automatik att veta vad som kan göras, i vilken ordning det ska göras eller vilka metoder som finns att tillgå. I kemiföretaget fanns ett stort engagemang för mångfaldsfrågor, men det saknades kunskap om förändringsarbete. Det resulterade i att de fokuserade på att rekrytera kvalificerad utlandsfödd personal, men inte var uppmärksamma på att dessa personer rekryterades till positioner som inte erbjöd någon möjlighet till karriärutveckling. På så sätt bidrog mångfaldsarbetet till att upprätthålla en ojämlikhetsregim där ledningspositioner och positioner med karriärmöjligheter befolkades av infödda svenskar och i princip alla utrikes födda medarbetare fanns på lägre nivåer och saknade karriärmöjligheter. Det blottar en avsaknad av maktperspektiv i förändringsarbetet (Benschop m.fl. 2015; Wahl m.fl. 2018), en medvetenhet om att det finns strukturella maktojämlikheter i samhället och i organisationer och att dessa maktojämlikheter inte är naturliga utan något vi tillsammans skapar. Förändringsarbetets potential att motverka ojämlikhet och främja jämlikhet uteblir eller äventyras om det bygger på en syn på skillnader som reducerar individer till fasta kategorier, och om organisationspraktiker och människor antas kunna vara neutrala och objektiva.

I flera av de andra studerade företagen fanns en medvetenhet om att det inte räcker med att fokusera på fördelningar, utan att kulturen måste förändras, bland annat behöver normer vidgas så att fler kan passa in utan att behöva anpassa sig. Dock ser vi att det finns en ten- 
dens att förändringsarbetet blir alltmer individfokuserat (SOU 2014:80). Ett tydligt uttryck för det är den stora vurmen för utbildningar om omedvetna fördomar. Individen är en viktig komponent i förändringsarbetet, men förändringsarbete som riktar in sig på individnivån vilar på en överdriven tilltro till individens handlingsförmåga och bortser delvis eller helt från att vårt handlande påverkas av det strukturella sammanhang vi befinner oss i. Det lägger också ett för stort ansvar på enskilda personer att både åstadkomma förändringar och ta ansvar för misslyckanden i förändringsarbetet. Noon (2018) hävdar dock att ett fokus på individen paradoxalt nog skulle kunna leda till att individer stimuleras att djupare granska de strukturer och kulturer som upprätthåller fördomarna och uppnår en större förståelse för hur maktrelationer skapas och upprätthålls.

Kunskap om förändringsarbete handlar också om att inse att det inte finns en viss metod som är bäst eller räcker med ett enda initiativ. Ojämlikhet är ett komplext problem och förändring kräver ett kontinuerligt arbete som innefattar många metoder. Det är intressant att notera att organisationer som anser sig vara framgångsrika i sitt förändringsarbete utmärks av att de använder många metoder samtidigt, och om en satsning misslyckas avskriver de inte frågan utan tar istället lärdom inför nästa steg (SOU 1994:3). De företag som vi studerat som har mångfald som en del av sin strategi och värdegrund har goda förutsättningar att få till stånd förändringar, då det borgar för att de inte ger upp i första taget.

Vi har konstaterat att insikter från den kritiska mångfaldsforskningen inte är tillräckliga för att åstadkomma förändring, men de är viktiga för att kunna utforma ett mångfaldsarbete med förändringspotential. De gör det också möjligt att som chef kritiskt reflektera över sin egen praktik i syfte att kontinuerligt utveckla sitt förändringsarbete. Samarbetet mellan praktiken och den kritiska mångfaldsforskningen är också avgörande för att generera kunskap om förändringsarbete. Vi vill därför bjuda in både praktiker och forskare till att fortsätta bidra med kritiska perspektiv på mångfaldsarbete för att på så sätt hitta vägar till att utmana och förändra ojämlikhetsregimer i samhället och i organisationer. 


\section{Slutsatser}

I detta kapitel har vi diskuterat mångfaldsarbetets potential att förändra organisationers ojämlikhetsregimer utifrån en studie av sex svenska företag med ett ambitiöst mångfaldsarbete. Med hjälp av tidigare forskning om mångfaldsarbete har vi lyft fram och diskuterat på vilket sätt dessa företag har definierat och kartlagt mångfald i sin organisation, hur de har utformat sina mångfaldsstrategier och vilka metoder de har anammat.

Vår diskussion har synliggjort komplexiteten i detta förändringsarbete. Att människor delas in i olika kategorier är kopplat till etablerade ojämlikhetsregimer, varför varje del av ett förändringsarbete, från val av definitioner till strategier och metoder, behöver förstås mot bakgrund av rådande maktstrukturer. Det är på grund av denna komplexitet som förändringsaktörer trots goda avsikter kan bidra till att upprätthålla ojämlikhetsregimer. Det finns därför heller inte någon metod som alltid fungerar bäst, utan varje alternativ har sina möjligheter och begränsningar. Vi har emellertid pekat på att en vilja att skapa mångfald och motverka ojämlikheter, kunskap om ojämlikheter samt kunskap om förändringsarbete är tre aspekter som påverkar mångfaldsarbetets potential att åstadkomma ett mer jämlikt arbetsliv och samhälle.

\section{Referenser}

Acker, J. (2006) "Inequality regimes: Gender, class, and race in organizations", Gender \& Society 20(4):441-464.

Anand, R. \& Winters, M-F. (2008) "A retrospective view of corporate diversity training from 1964 to the present", Academy of Management Learning \& Education $7(3): 356-372$.

Ashcraft, K.L. (2009) "Gender and diversity: Other ways to make a difference." I M. Alvesson, T. Bridgman \& H. Willmott (red.) The Oxford Handbook of Critical Management Studies. Oxford: Oxford University Press.

Benschop, Y., Holgersson, C., van den Brink, M. \& Wahl, A. (2015) "Future challenges for practices of diversity management in organizations". I R. Bendl, I. Bleijenbergh, E. Henttonen \& A.J. Mills. (red.) The Oxford Handbook of Diversity in Organizations. Oxford: Oxford University Press.

Bond, M.A. \& Pyle, J.L. (1998) "Diversity dilemmas at work", Journal of Management Inquiry 7(3):252-269.

Callerstig, A-C. (2011) "Utbildning för en jämställd verksamhet”. I K. Lindholm (red.) Jämställdhet $i$ verksamhetsutveckling. Lund: Studentlitteratur. 
Holgersson, C. \& Romani, L. (2020) "Tokenism revisited: when organizational culture challenges masculine norms, the experience of token is transformed", European Management Review 17(3):649-661.

Holvino, E. \& Kamp, A. (2009) "Diversity management: Are we moving in the right direction? Reflections from both sides of the North Atlantic", Scandinavian Journal of Management 25(4):395-403.

Janssens, M., \& Zanoni, P. (2014) "Alternative diversity management: Organizational practices fostering ethnic equality at work", Scandinavian Journal of Management 30(3):317-331

Kalev, A., Dobbin, F. \& Kelly, E. (2006) "Best practices or best guesses? Assessing the efficacy of corporate affirmative action and diversity policies", American Sociological Review 71(4):589-617.

Kelly, E. \& Dobbin, F. (1998) "How affirmative action became diversity management: Employer response to antidiscrimination law, 1961 to 1996", American Behavioral Scientist 41(7):960-984.

King, D. \& Learmonth, M. (2015) "Can critical management studies ever be 'practical'? A case study in engaged scholarship", Human Relations 68(3):353-375.

Kulik, C.T. \& Roberson, L. (2008) "Diversity initiative effectiveness: What organizations can (and cannot) expect from diversity recruitment, diversity training, and formal mentoring programs". I A.P. Brief (red.) Diversity at work. New York: Cambridge University Press.

Leiva, A. (2019) Three faces of diversity rhetoric: Managerialization, marketing and ambiguity. Stockholm: Stockholms universitet.

Linnehan, F. \& Konrad, A.M. (1999) "Diluting diversity: Implications for intergroup inequality in organizations", Journal of Management Inquiry 8(4):399-414.

Litvin, D.R. (200o). Defamiliarizing Diversity: A Cultural Studies Analysis. Avhandling. Amherst, MA: University of Massachusetts at Amherst.

Lorbiecki, A. \& Jack, G. (2000) "Critical turns in the evolution of diversity management", British Journal of Management 11: S17-S31.

Meyerson, D.E. \& Scully, M.A. (1995) "Crossroads tempered radicalism and the politics of ambivalence and change", Organization Science 6(5):585-60o.

Noon, M. (2007) "The fatal flaws of diversity and the business case for ethnic minorities", Work, Employment and Society 21(4):773-784.

Noon, M. (2018) "Pointless diversity training: Unconscious bias, new racism and agency", Work, Employment and Society 32(1):198-209.

Näringsdepartementet (2000) Alla lika olika - mångfald i arbetslivet. Ds 200:69. https://www.regeringen.se/49baf8/contentassets/22438be801c84bf9a1e35dcc1e1e2057/alla-ar-lika-olika---mangfald-i-arbetslivet (hämtad 2019-01-18).

Omanović, V. (2009) "Diversity and its management as a dialectical process: Encountering Sweden and the US", Scandinavian Journal of Management 25(4):352-362.

Oswick, C. \& Noon, M. (2014) "Discourses of diversity, equality and inclusion: trenchant formulations or transient fashions?", British Journal of Management 25(1):23-39.

Proffice (2015) Mångfaldsbarometer 2015. https://mb.cision.com/Public/969/9751695/ abgf7118f19b703a.pdf (hämtad 2019-01-18).

Roberson, Q. M. (2006) "Disentangling the meanings of diversity and inclusion in organizations", Group \& Organization Management, 31(2):212-236. 
Romani, L., Holck, L. \& Risberg, A. (2019) "Benevolent discrimination: Explaining how human resources professionals can be blind to the harm of diversity initiatives", Organization 26(3):371-39o.

SCB/Statistiska centralbyrån (2018) På tal om kvinnor och män. Lathund om jämställdhet 2018. Örebro: SCB.

Schwabenland, C. \& Tomlinson, F. (2015) "Shadows and light: Diversity management as phantasmagoria", Human Relations 68(12):1913-1936.

SFS 2008:567. Diskrimineringslagen. Stockholm: Justitiedepartementet.

SOU 2004:43. Den könsuppdelade arbetsmarknaden. Betänkande av utredningen om den könssegregerade svenska arbetsmarknaden. Stockholm: Fritzes.

SOU 2006:60. På tröskeln till lönearbete: Diskriminering, exkludering och underordning av personer med utländsk bakgrund. Rapport av utredningen om makt, integration och strukturell diskriminering. Stockholm: Fritzes.

SOU 2014:80. Ökad medvetenhet men långsam förändring: om kvinnor och män på ledande positioner i svenskt näringsliv. Stockholm: Fritzes.

SOU 2017:92. Transpersoner i Sverige. Förslag för stärkt ställning och bättre levnadsvillkor. Betänkande från utredningen Stärkt ställning och bättre levnadsvillkor för transpersoner. Stockholm: Fritzes.

Wahl, A., Holgersson, C., Höök, P. \& Linghag, S. (2018) Det ordnar sig. Teorier om organisation och kön. Tredje reviderade upplagan. Lund: Studentlitteratur.

Wickert, C. \& Schaefer, S.M. (2015) "Towards a progressive understanding of performativity in critical management studies", Human Relations 68(1):107-130.

Zanoni, P. \& Janssens, M. (2004) "Deconstructing difference: The rhetoric of human resource managers' diversity discourses", Organization Studies 25(1):55-74.

Özbilgin, M., Tati, A., Ipek, G. \& Sameer, M. (2014) The Business Case for Diversity Management. London: ACCA. https://www.accaglobal.com/content/dam/acca/ global/PDF-technical/human-capital/pol-tp-tbcfdm-diversity-management. pdf (hämtad 2020-06-22). 